\title{
KAJIAN KRITERIA INVESTASI KONVENSIONAL DAN LINGKUNGAN PETERNAKAN BABI DI KOTA TOMOHON
}

\author{
Franky N.S. Oroh*, S.A.E. Moningkey,I.D.R. Lumenta
}

Fakultas Peternakan Universitas Sam Ratulangi Manado, 95115

\begin{abstract}
ABSTRAK
Penelitian ini bertujuan untuk menganalisis kelayakan usaha berdasarkan kriteria investasi secara konvensional dan lingkungan, yaitu mengetahui sejauh mana kelayakan ekonomi berdasarkan kriteria investasi dengan mempertimbangkan biaya-biaya internal (biaya konvensional) dan biaya eksternalilas (biaya lingkungan) dalam agribisnis peternakan babi.Penelitian ini dilaksanakan di Kota Tomohon, di mana peternakan sampel yaitu memiliki kriteria skala usaha sebesar $<1.000,1.000-5.000$ dan >5.000. Analisis yang digunakan yaitu analisis kriteria investasi untuk melihat kelayakan ekonomi usaha, dengan perhitungan Net Present Value (NPV), Benefit Cost Ratio (BCR) dan Internal Rate of Return (IRR).Nilai NPV secara konvensional ataupun secara eksternalitas ternyata lebih besar dari nol atau positif, hasil ini menunjukkan bahwa perusahaan sampel secara konvensional sudah layak secara finansial, demikian juga dengan rencana pengembangan investasi eksternalitas juga sudah layak secara finansial. Nilai IRR secara konvensional dan eksternalitas lebih besar dari satu, hasil ini menunjukkan bahwa perusahaan sampel dengan investasi konvensional dan eksternalitas masih menguntungkan, apalagi jika investasi ini dilihat secara lingkungan, akan lebih menguntungkan karena akan mengurangi dampak lingkungan. Nilai BC ratio secara konvensional dan eksternalitas lebih besar dari satu, hasil ini menunjukkan bahwa pengembangan investasi eksternalitas layak dilanjutkan.
\end{abstract}

Kata kunci: Ekonomi, Lingkungan, Peternakan Babi, Tomohon

*Korespondensi (corresponding author):

Email: frankyorohsptmsi@yahoo.co.id

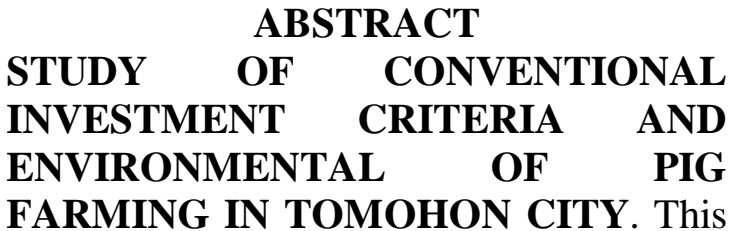

study aims to analyze the feasibility of conventional (private) and environment (externalities) investment criteria, which determine the extent of the economic feasibility of the externalities investment criteria taking into account the private costs (conventional costs) and externalities costs (environmental costs) in the pig farm agribusiness. This research was conducted in Tomohon, where the sample pig farms that have business scale criterion of $<1,000,1,000-5,000$, and $>5,000$ heads. The analysis used the analysis of investment criteria to look at the externalities economic feasibility of the pig farms, with the calculation of Net Present Value (NPV), Benefit Cost Ratio (BCR) and Internal Rate of Return (IRR). NPV of conventionally and externalities was greater than zero or positive, these results suggest that the companies have been conventionally sampled financially feasibility, as well as the investment plan of externalities. IRR conventional and externalities is greater than one, these results indicate that the samples with conventional and externalities investment companies are still profitable, especially if the investment is viewed in the environment, it would be beneficial as it will reduce the environmental impact. BC ratio values conventionally and externalities is greater than one, these results suggest that the externalities investment is feasible for conducting.

Keywords :Economy, Environment, Pig Farms, Tomohon 


\section{PENDAHULUAN}

Pembangunan

peternakan

ditujukan untuk mewujudkanpenyediaan dan keamanan pangan yang berwawasan lingkungan dan berkelanjutandengan mengoptimalkan pemanfaatan sumberdaya lokal sudah menjadi tuntutan global dewasa ini, sehingga visi Direktorat Jenderal Peternakan dan Kesehatan Hewan Tahun 2010-2014 yaitu mewujudkanpeternakan dan kesehatan hewan yang berdaya saing dan berkelanjutandengan mengoptimalkan pemanfaatan sumberdaya lokal untuk mewujudkanpenyediaan dan keamanan pangan hewani serta meningkatkankesejahteraan

peternak(Sajowet al; 2014; Loho et al., 2014).

Dalam rangka mewujudkan peternakan yang berbasis agribisnis maka pengembangan peternakan merupakan alternatif yang perlu diperhitungkan dengan didasarkan pada sumberdaya termasuk sumberdaya lingkungan(Ditjennak Deptan, 2011; Mangare et al., 2016).Kegiatan usaha budidaya ternak babi di pemukiman akan menimbulkan permasalahan yang kompleks terhadap lingkungan hidup. Permasalahan yang paling sering adalah permasalahan limbah dari peternakan babi terutama kotoran dan urine yang menyebabkan bau, di mana terjadi kesulitan pembuangan hasil samping berupa limbah dan permasalahan lingkungan sekitar usaha (Wenedi 2018).

Kajian lingkungan baik negatif maupun positif secara ekonomi biasanya disebut eksternalitas. Morris (2013) mengemukakan bahwa eksternalitas sebagai biaya dan manfaat yang diakibatkan oleh perubahan lingkungan secara fisik hayati.Eksternalitas merupakan efek samping atau dampak yang timbul karena adanya keterkaitan antara aktivitas ekonomi yang satu dengan yang lainnya (Mukhlis, 2011). Dalam usaha peternakan eksternalitas memiliki pengaruh yang diharapkan maupun tidak diharapkan (tidak langsung), di manaeksternalitas bisa positif atau negatif. Eksternalitas positif yang memberikan manfaat bagi peternak atau masyarakat lainnya, sedangkan eksternalitas negatif menghasilkan dampak yang merugikan bagi orang lain. Sebagai contoh, limbah kotoran ternak bisa menjadi pupuk organik (eksternalitas positif) ataupun polusi (Warouw et al., 2014).

Usaha ternak babi memiliki potensi pengembangan di Kota Tomohon disebabkan investasi dalam usaha ini tidak memerlukan biaya dan lahan yang besar, disamping itu pengembalian modalnya relatif lebih cepat, dan walaupun pengembangan agribisnis ternak babi terbatas karena faktor sosial budaya 
(agama) tetapi di Sulawesi Utara khususnya Tomohon mempunyai prospek yang baik karena adanya permintaan pasar lokal dan daerah sekitarnya yang tinggi, serta tidak ada kendala sosial budaya.

Populasi ternak besar yang terdiri dari sapi, kuda, kambing, dan babi pada tahun 2011 berdasarkan data Tomohon Dalam Angka Tahun 2012, secara berturut-turut adalah 2.976 ekor, 277 ekor, 895 ekor, dan 73.620 ekor, di mana populasi terbanyak yaitu ternak babi. Hal ini menunjukkan ternak babi merupakan salah satu komoditas ternak yang perlu dikembangkan serta mendapat perhatian pemerintah karena mampu menghasilkan produk daging yang bernilai gizi tinggi serta harganya dapat dijangkau masyarakat.

Pengembangan dan meningkatkan produktivitas usaha ternak babi dengan mempertimbangkan faktor lingkungan, maka perlu dilakukan suatu kajian melalui penelitian tentang analisis ekonomi agribisnis ternak babi berbasis lingkungan secara konvensional (privat) dan analisis eksternalitas (lingkungan), berdasarkan kriteria-kriteria investasi agribisnis ternak babi di Kota Tomohon.Berdasarkan latar belakang, maka rumusan masalah yang akan dikaji dalam penelitian ini yaituSeberapa besar biayainternal (biaya konvensional), biaya eksternal(biaya lingkungan), dan keuntungan dalam agribisnis peternakan babi di Kota Tomohon serta sejauh mana kelayakan ekonomi berdasarkan kriteria investasi dengan mempertimbangkan biaya-biaya internal (biaya konvensional) dan biaya eksternal (biaya lingkungan) dalam agribisnis peternakan babi di Kota Tomohon.

\section{METODE PENELITIAN}

\section{Lokasi Penelitian}

Penelitian ini akan dilaksanakan pada usaha peternakan babi di Kota Tomohon dengan menggunakan metode survey(Morissan, 2017),terhadap pemilik usaha atau pengusaha ternak babi sebagai unit penelitian di Kota Tomohon.Metode penilaian ekonomi menggunakan data primer berdasarkan borang kaji selidik (questionairres) yangtelah disusun sesuai dengan objektif kajian (Hidayatullah, et al., 2011).

Penentuan lokasi desa sampel dan perusahaan sampel dilakukan secara “purposive sampling”.Desa sampel dipilih dengan kriteria desa/kelurahan yang memiliki populasi ternak babi yang banyak dan terdapat peternak komersial. Perusahaan yang diambil dan dikaji secara studi kasus (case study) yaitu perusahaan peternakan babi yang mewakili beberapa perusahaan peternakan dan memiliki populasi ternak babi terbanyak, dengan kriteria perusahaan telah berusaha minimal 
dua tahun dan jumlah ternak yang dipelihara sesuai skala usaha sebesar $<1.000,1.000-5.000$ dan $>5.000$, pada setiap skala usaha masing-masing dipilih satu peternak sampel yang akan dievaluasi prospek kelayakan usahanya secara eksternalitas selama sepuluh tahun ke depan.

\section{Analisis Data}

Model analisis ekonomi dalam penelitian ini difokuskan pada analisis cost-benefit analysis (CBA) dengan memperhitungkan biaya eksternalitas dan keuntungan lingkungan di dalamnya. Analisis cost-benefit analysis yang digunakan yaitu berdasarkan kriteriakriteria investasi untuk melihat kelayakan ekonomi usaha, yang di dahului dengan perhitungan cash flow (arus tunai) usaha selama satu tahun produksi dan dilanjutkan dengan perhitungan Benefit Cost Ratio (BCR), selain Net Present Value (NPV) dan Internal Rate of Return (IRR) dengan memperhitungkan biaya eksternalitas dan keuntungan lingkungan di dalamnya.

Analisis finansial dalam analisis ekonomi di atas, kajian lingkungan juga menggunakan kriteria-kriteria investasi untuk melihat kelayakan usaha dengan di dahului perhitungan cash flow (arus tunai) usaha selama setahun produksi dan dilanjutkan dengan perhitungan $\mathrm{BC}$ Ratio namun dengan memasukkan biaya-biaya eksternalitas dampak lingkungan dalam perhitungan biaya total dan memasukkan pendapatan lingkungan dari harga dan nilai moneter dari produk ikutan (by product) dan produk limbah (waste product). Dengan dimasukkannya biaya eksternalitas dan pendapatan lingkungan dalam model analisis finansial di atas menurut Gray et al., (2002) maka untuk penelitian ini PV benefit didasarkan pada perhitungan benefit (pendapatan) dan cost (biaya) sebagai berikut:

Benefit $=$ nilai produksi + nilai by and waste product

Cost = biaya + biaya eksternalitas

Sehingga perhitungan BC Ratio, menjadi:

Environment PV (Benefit +waste value) BC Ratio = PV (cost + Externalities)

Di mana:

Environment BC Ratioyaitu Perbandingan antara Penerimaan dan Biaya dalam agribisnis peternakan babi memasukkan biaya eksternalitas dan penerimaan lingkungan dalam perhitungan.

Externalities PV Benefi yaitu Nilai sekarang dari penerimaan yang nanti diperoleh pada periode mendatang memasukkan penerimaan lingkungan dalam perhitungan.

Externalities PV Cost yaitu Nilai sekarang dari biaya yang nanti dikeluarkan pada 
periode mendatang memasukkan biaya eksternalitas dalam perhitungan.

Demikian juga perhitungan benefit (pendapatan) dan cost (biaya) untuk perhitungan Externalities NPV dan Externalities IRR

\section{HASIL DAN PEMBAHASAN}

\section{Karakteristik perusahaan peternakan sampel}

Perusahaan peternakan babi yang menjadi sampel penelitian berada di Kecamatan Tomohon Utara dan Kecamatan Tomohon Barat, karena wilayah ini ditetapkan sebagai kawasan sentra produksi peternakan di Kota Tomohon.Berdasarkan penjelasan Kepmentan No. 404/kpts/OT.210/6/2002 tentang Pedoman Perizinan dan Pendaftaran Usaha Peternakan, bahwa yang tergolong perusahaan peternakan babi yaitu skala usaha $>125$ ekor. Dari kedua kecamatan tersebut diambil perusahaan peternakan babi sampel berdasarkan kriteria skala usaha yaitu $<1.000$ ekor, 1.000-5.000 ekor, dan >5.000 di mana masing-masing skala usaha diambil satu peternak yang mewakili.

Ketiga perusahaan peternakan babi yang menjadi sampel merupakan usaha milik sendiri, dengan kapasitas produksi masing-masing sebesar 500, 2.000, dan 7.000 ekor yang berdasarkan Kepmentan No. 404/kpts/OT.210/6/2002 ketiga peternakan sampel sudah tergolong perusahaan yang harus memiliki izinusaha peternakan. Kapasitas kandang ketiga perusahaan sampel lebih dari 500 ekor tentu sudah direncanakan sesuai lokasi dan ketersediaan sumberdaya dan dana.Karakteristik ketiga usaha peternakan babi sampel dapat dilihat pada Tabel 1 .

Kandang merupakan hal yang sangat penting dalam menunjang usaha dan untuk memudahkan tatalaksana seperti memberi makan,memandikan babi dan mengontrol penyakit serta memberikan kenyamanan pada ternak (Risman 2016; Timbulusetal., 2017).Selain itu kandang juga harus memberikan kenyamanan bagi manusia(Sapancaet al., 2015).Namun di antara ketiga perusahaan sampel, hanya Perusahaan $\mathrm{C}$ yang telah cukup representatif memberikan kenyamanan bagi manusia baik peternak dan tenaga kerjanya, maupun masyarakat sekitar.Pada ketiga peternakan sampel hanya Perusahaan $\mathrm{C}$ yang masih memiliki areal untuk peningkatan kapasitas usaha, sehingga masih memungkinkan investasi konstruksi kandang untuk pengembangan usaha.Konstruksi kandang pada ketiga peternakan sampel sudah ada bagian yang perlu direnovasi sehingga perlu mengeluarkan biaya investasiterutama untuk biaya eksternalitas.

Limbah kotoran ternak babi di lokasi perkandangan pada ketiga 
perusahaan peternakan babi sampel kandang.Penyaluran air limbah dari disalurkan ke tempat penampungan perkandangan ke tempat penampungan limbah, kemudian sebagian limbah kotoran ternak dari tempat penampungan dipindahkan ke karung-karung untuk limbah dan dibiarkan meresap ke dalam tanah, dan sebagian kecil mengalir ke dipergunakan sebagai pupuk sungai.

Tabel 1. Karakteristik Perusahaan Peternakan Sampel

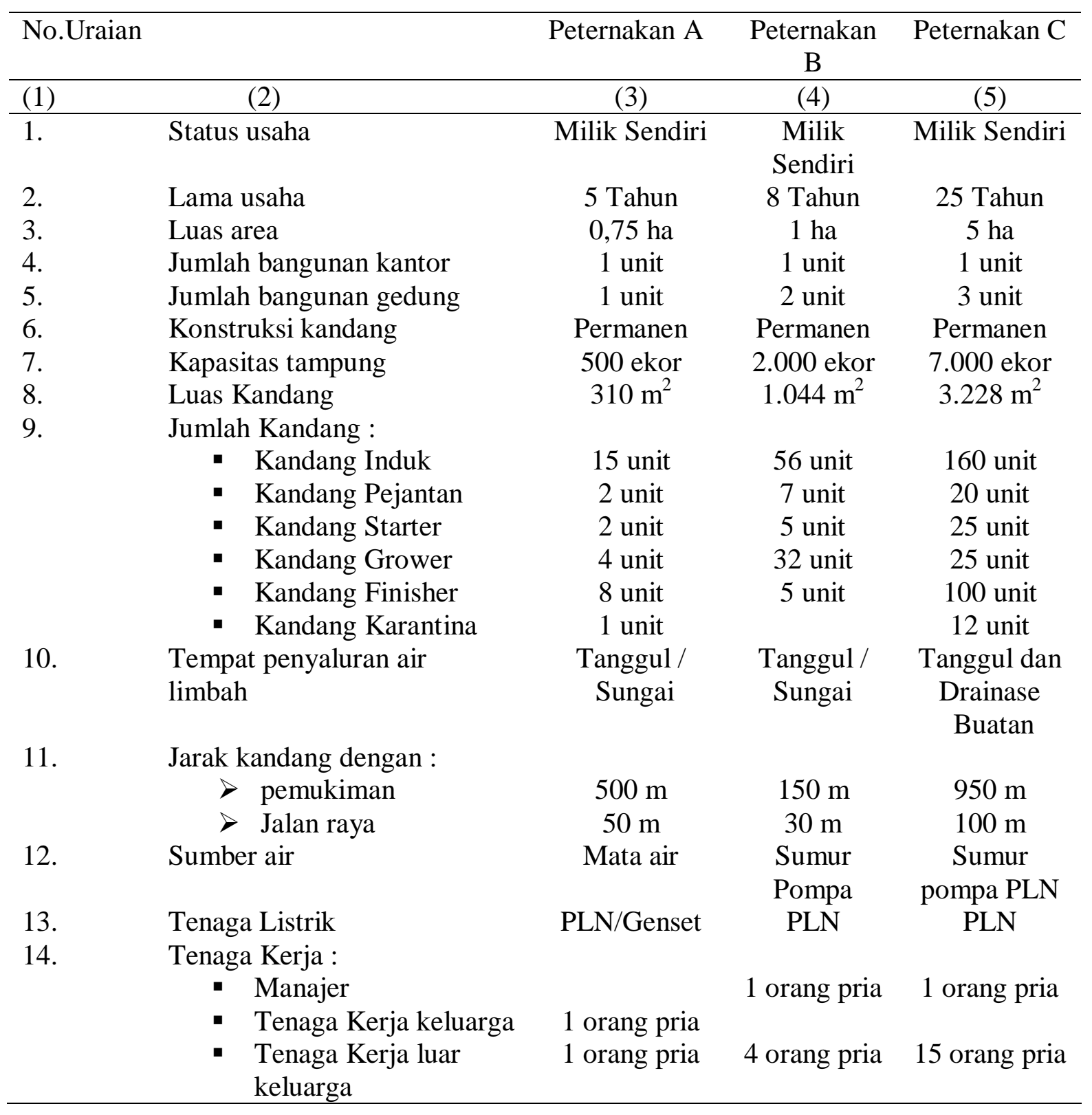


Penataan saluran air limbah kandang pada perusahaan peternakan $\mathrm{C}$ sudah cukup baik, namun pada dua perusahaan A dan B masih perlu ditingkatkan. Hal ini perlu ditingkatkan karena pada kedua perusahaan ini masih menyebarkan bau yang relatif jauh bahkan sampai ke jalan raya, sehingga agak mengganggu masyarakat sekitar maupun pengguna jalan raya.

\section{Biaya Produksi, Penerimaan dan Keuntungan}

Untuk kajian eksternalitas, biaya produksi dalam suatu usaha terdiri dari biaya langsung dan tidak langsung (Warouw et al., 2014). Biaya langsung yaitu biaya yang berhubungan langsung dengan kepentingan produksi, seperti biaya investasi (biaya pembangunan konstruksi, biaya peralatan), biaya operasi dan pemeliharaan (biaya penyusutan, bunga bank, tanah, modal kerja, biaya lain). Sedangkan biaya tidak langsung yaitu biaya yang perlu diperhitungkan dalam menganalisis proyek yang dikenal dengan biaya eksternalitas (Dewi, 2011; Sajowet al., 2014).

Berdasarkan hasil penelitian para peternak babi sampel di Kota Tomohon mengeluarkan biaya produksi ekternalitas yaitu biaya investasi dan operasional secara konvensional dan biaya
eksternalitas.Komposisi biaya usaha peternakan babi sampel di Kota Tomohon dapat dilihat pada Tabel 2.

Perusahan ternak babi sampel mengeluarkan biaya terbesar yaitu biaya pakan sebesar 83,77\%, 89,17\% dan $89,73 \%$. Hal ini ternyata lebih besar dibanding dengan yang dikatakan oleh Timbulus et al. (2017),bahwa 60-80\% dari biaya dihabiskan untuk biaya pakan. Penyebabnya karena makin mahalnya harga bahan baku dan konsentrat di pasaran, sehubungan dengan kenaikan harga-harga berbagai bahan yang disebabkan oleh kenaikan harga BBM dan tingkat inflasi.

Biaya eksternalitas pada ketiga peternakan masih sangat rendah, di mana pada ketiga perusahan ternak babi sampel hanya mengeluarkan biaya lingkungan sebagai biaya eksternalitas masing-masing sebesar 0,39\% (Perusahaan A), 0,95\% (Perusahaan B) dan 0,23\% (Perusahaan C). Dari ketiga perusahaan tersebut, justru perusahaan dengan kapasitas produksi paling besar yaitu Perusahaan $\mathrm{C}$ yang paling kecil biaya eksternalitasnya, hal ini karena lokasi dan menataan drainase yang lebih representatif sehingga biaya lingkungan yang dikeluarkan lebih sedikit prosentasenya dibanding yang lainnya. 
Tabel 2.Komposisi Biaya Usaha Peternakan Babi Sampel di Kota Tomohon Tahun 2018

\begin{tabular}{|c|c|c|c|}
\hline \multirow[t]{2}{*}{ Perusahaan } & \multirow[t]{2}{*}{ Komponen Biaya } & \multicolumn{2}{|l|}{ Jumlah Biaya } \\
\hline & & $\mathrm{Rp}$ & $\%$ \\
\hline (1) & (2) & (3) & (4) \\
\hline \multirow[t]{13}{*}{ Perusahaan A } & Biaya Tetap : & & \\
\hline & $\circ$ Penyusutan Kandang Peralatan & 5.356 .500 & 1,33 \\
\hline & o Nilai Sewa Tanah & 15.500 .000 & 3,84 \\
\hline & o Listrik & 1.600 .000 & 0,40 \\
\hline & ○ PBB, Pajak Usaha, Retrebusi,dll & 790.000 & 0,20 \\
\hline & Biaya Variabel : & & \\
\hline & ○ Biaya Bibit & 3.100 .000 & 0,74 \\
\hline & - Biaya Pakan & 337.827 .264 & 83,77 \\
\hline & - Biaya Obat dan Vaksin & 753.060 & 0,19 \\
\hline & - Transportasi & 10.950 .000 & 2,72 \\
\hline & - Biaya Tenaga Kerja & 29.925 .000 & 6,43 \\
\hline & Biaya Eksternalitas & 1.587 .500 & 0,39 \\
\hline & Total & 403.289 .324 & 100,00 \\
\hline \multirow[t]{13}{*}{ Perusahaan B } & Biaya Tetap : & & \\
\hline & $\circ$ Penyusutan Kandang/Peralatan & 21.524 .000 & 0,73 \\
\hline & - Nilai Sewa Tanah & 55.000 .000 & 1,87 \\
\hline & O Listrik & 7.200 .000 & 0,25 \\
\hline & ○ PBB,Pajak Usaha,Retribusi, dll & 101.816 .850 & 3,47 \\
\hline & Biaya Variabel : & & \\
\hline & $\circ$ Biaya Bibit & 22.500 .000 & 0,77 \\
\hline & - Biaya Pakan & 2.617.659.423 & 89,17 \\
\hline & - Biaya Obat dan Vaksin & 753.060 & 0,03 \\
\hline & o Transportasi & 18.250 .000 & 0,62 \\
\hline & $\circ$ Biaya Tenaga Kerja & 63.125 .000 & 2,15 \\
\hline & Biaya Eksternalitas & 27.875 .000 & 0,95 \\
\hline & Total & 2.935 .703 .333 & 100,00 \\
\hline \multirow[t]{13}{*}{ Perusahaan $\mathrm{C}$} & Biaya Tetap : & & \\
\hline & o Penyusutan Kandang/Peralatan & 67.930 .000 & 0.80 \\
\hline & - Nilai Sewa Tanah & 170.000 .000 & 2,01 \\
\hline & ○ Listrik & 14.500 .000 & 0,17 \\
\hline & ○ PBB,Pajak Usaha,Retribusi, dll & 290.940 .818 & 3,44 \\
\hline & Biaya Variabel : & & \\
\hline & - Biaya Bibit & 67.500 .000 & 0,80 \\
\hline & o Biaya Pakan & 7.592.879.721 & 89,73 \\
\hline & - Biaya Obat dan Vaksin & 25.506 .000 & 0.30 \\
\hline & o Transportasi & 18.250 .000 & 0,22 \\
\hline & - Biaya Tenaga Kerja & 181.925 .000 & 2,15 \\
\hline & Biaya Eksternalitas & 19.875 .000 & 0,23 \\
\hline & Total & 8.461 .556 .539 & 100,00 \\
\hline
\end{tabular}

Kajian ekonomi dalam penelitian ini difokuskan pada analisis cost-benefit analysis (CBA) dengan memperhitungkan biaya eksternalitas, penerimaan dan keuntungan lingkungan di dalamnya pada usaha peternakan babi sampel di Kota Tomohon, sebagaimana dapat dilihat pada Tabel 3 menunjukkan bahwa analisis 
secara konvensional (private), ketiga perusahaan sampel memperoleh keuntungan selama setahun (2018) masing-masing sebesar Rp.76.611.176 (Perusahaan A), Rp.1.148.716.667 (Perusahaan B) dan Rp.3.200.591.261 (Perusahaan C). Namun secara terpisah, melalui perhitungan penerimaan dan biaya lingkungan (eksternalitas) menunjukkan bahwa perusahaan B tidak memperoleh keuntungan, bahkan justru mengalami kerugian sebesar Rp.18.150.000.

Tabel 3. Biaya, Penerimaan Dan Keuntungan Konvensional Dan Eksternalitas Usaha Peternakan Babi Sampel Di Kota Tomohon Tahun 2018

\begin{tabular}{|c|c|c|c|c|}
\hline Perusahan & Uraian & Konvensional & $\begin{array}{c}\text { Jumlah } \\
\text { (Rp/Thn) } \\
\text { Eksternalitas }\end{array}$ & Total \\
\hline \multirow[t]{2}{*}{ (1) } & $(2)$ & (3) & $(4)$ & $(5)-(3)(1)$ \\
\hline & Penerimaan & 478.313 .000 & 3.972 .000 & 482.285 .000 \\
\hline \multirow[t]{2}{*}{ Perusahaan A } & Biaya Produksi & 401.701 .824 & 1.587 .500 & 403.289 .324 \\
\hline & Keuntungan & 76.611 .176 & 2.384 .500 & 77.408 .176 \\
\hline \multirow{3}{*}{ Perusahaan B } & Penerimaan & 4.056 .545 .000 & 9.752 .000 & 4.066 .270 .000 \\
\hline & $\begin{array}{l}\text { Biaya Produksi } \\
\text { Keuangan }\end{array}$ & 2.907 .828 .333 & 27.875 .000 & 2.935 .703 .333 \\
\hline & Keuntungan & 1.148 .716 .667 & $(-18.150 .000)$ & 1.102 .691 .667 \\
\hline \multirow{3}{*}{ Perusahaan C } & Penerimaan & 11.642 .272 .800 & 22.500 .000 & 11.664 .772 .800 \\
\hline & Biaya Produksi & 8.441 .681 .539 & 18.875 .000 & 8.461 .556 .539 \\
\hline & Keuntungan & 3.200 .591 .261 & 2.625 .000 & 3.183 .341 .261 \\
\hline
\end{tabular}

Tabel 4. Analisis Kriteria Investasi Eksternalitas Usaha Peternakan Babi di Kota Tomohon Tahun 2019-2028

\begin{tabular}{clrrr}
\hline Perusahaan & Indikator & \multicolumn{1}{c}{ Konvensional } & \multicolumn{1}{c}{ Eksternalitas } & Ket \\
\hline (1) & & \multicolumn{1}{c}{$(3)$} & \multicolumn{1}{c}{$(4)$} & $(5)$ \\
& NPV & 6.100 .340 .492 & 6.114 .790 .115 & \\
Nerusahaan A & 4.779 .981 .750 & 4.792 .552 .532 & \\
& NPV & 33,10 & 33,12 & GO \\
& IRR & 2,99 & 2,99 & \\
& BCR & 2,82 & 2,81 & \\
& BCR & 13.061 .327 .035 & 12.772 .053 .345 & \\
& NPV & 10.655 .455 .862 & 10.429 .580 .618 & \\
Perusahaan B & NPV & 37,14 & 37,26 & GO \\
& IRR & 1,60 & 1,58 & \\
& BCR & 1,57 & 1,55 & \\
& BCR & 26.666 .910 .038 & 26.495 .338 .085 & \\
Perusahaan C & NPV & 22.045 .047 .735 & 21.898 .703 .065 & \multirow{2}{*}{ GO } \\
& NPV & 38,85 & 38,82 & \\
& IRR & 1,43 & 1,42 & \\
& BCR & 1,41 & 1,40 & \\
& BCR & & & \\
& & & &
\end{tabular}


Hal tersebut terjadi karena perusahaan tersebut memperoleh penerimaan lingkungan yaitu nilai jual pemanfaatan pupuk kandang untuk pertanian hanya sebesar Rp.9.752.000 sementara itu perusahaan mengeluarkan biaya korbanan sebesar Rp.27.875.000 untuk mengeliminir dampak lingkungan demi keberlanjutan usahanya. Sebab kalau tidak demikian, dampak limbah akan menganggu lingkungan, sehingga akan dikomplain oleh masyarakat atau bahkan masyarakat akan meminta untuk menghentikan peternakan di lokasi tersebut yang.dapat berakibat peternak akan makin merugi.

Hasil analisis eksternalitas dengan penerimaan dan biaya kombinasi secara konvensional maupun lingkungan, menunjukkan bahwa ketiga perusahaan memperoleh keuntungan selama setahun masing-masing sebesar Rp.77.408.176 (Perusahaan A), Rp.1.102.691.667 (Perusahaan B) dan Rp.3.183.341.261 (Perusahaan C). Hal ini berarti bahwa sekalipun peternak mengorbankan dana untuk biaya lingkungan, namun masih tetap memberikan keuntungan finansial bagi usahanya. Untuk itu perlu dilakukan analisis finansial selama 10 tahun ke depan (2019-2028),

\section{Analisis Kriteria Investasi Ekternalitas Rencana Pengembangan Babi di Kota Tomohon Tahun 2019-2028}

Penelitian ini akan mengevaluasi rencana pengembangan secara eksternalitas (externalities) yaitu dengan memperhitungkan rencana investasi biaya lingkungan dan penerimaan ataupun nilai tambah (value added) secara lingkungan (externalities) bersamaan dengan perhitungan secara konvensional (private), untuk melihat apakah dengan investasi lingkungan akan layak secara finansial. Penelitian ini menggunakan tiga kriteria investasi yang pertama, yaitu NPV, IRR dan BC Ratio, dilakukan analisis finansial selama 10 tahun ke depan (2019-2028) berdasarkan data $\mathrm{T}_{0}$ Tahun 2018, untuk melihat prospek kelayakan usaha dengan meningkatkan investasi untuk biaya eksternalitas melaluianalisis kriteria investasi ekternalitas usaha peternakan babi sampel di Kota Tomohon.

Investasi lingkungan yang direncanakan para peternak sampel yaitu penataan kandang dan saluran pembuangan limbah kotoran ternak, terutama tanggul ataupun bak penampungan kotoran ternak yang berfungsi semacam septic tank untuk mengfermentasi dan mengurai kotoran ternak untuk menjadi slurry dan limbah cair yang dapat dialirkan ke saluran kali. Namun dari keterangan para responden 
bahwa pembuatan konstruksi ini direncanakan pada waktu yang berbeda dan dengan kemampuan dana yang dimiliki para peternak, di mana hasil analisis finansial secara eksternalitas rencana investasi ini dilihat pada Tabel 4.

Hasil analisis externalities cash flow yang dianalisis secara kriteria investasi sebagaimana dapat dilihat pada Tabel 4 menunjukkan nilai NPV ketiga perusahaan pada tingkat discount factor $10 \%$ secara konvensional ataupun secara eksternalitas ternyata lebih besar dari nol atau positif. Demikian juga nilai NPV pada tingkat discount factor $15 \%$ secara konvensional ataupun secara eksternalitas lebih besar dari nol atau positif.

Hasil ini menunjukkan bahwa ketiga perusahaan sampel secara konvensional memberikan pendapatan atau benefit yang lebih besar dari nol artinya sudah layak secara finansial, demikian juga dengan rencana investasi eksternalitas memberikan pendapatan atau benefit yang lebih besar dari nol artinya juga sudah layak secara finansial.Berdasarkan kriteria investasi hasil analisis ini menunjukkan bahwa pengembangan investasi eksternalitas pada perusahaan peternakan babi sampel di Kota Tomohon secara finansial layak untuk dilaksanakan.

Hasil analisis IRR pengembangan peternakan babi di Kota Tomohon untuk satu sampai sepuluh tahun mendatang dengan tingkat diskonto (discout factor) $10 \%$ dan $15 \%$ sesuai dengan kisaran tingkat bunga pasar berlaku sebagaimana dapat dilihat pada Tabel 4, menunjukkan nilai IRR ketiga perusahaan secara konvensional ternyata lebih besar dari satu, yaitu masing-masing sebesar $33,10 \%$, 37,14\% dan 38,85\%. Demikian juga secara eksternalitas ternyata lebih besar dari satu, yaitu masing-masing sebesar $33,12 \%, 37,26 \%$ dan 38,82\%, hasil ini menunjukkan bahwa ketiga perusahaan sampel dengan investasi eksternalitas pada pengembangan peternakan babi di Kota Tomohon selama sepuluh tahun ke depan dapat memberikan tingkat keuntungan finansial.

Pengembangan investasi eksternalitas peternakan babi di Kota Tomohon dapat memberikan tingkat keuntungan secara finansial, di mana investasi eksternalitas pengembangan peternakan babi masih menguntungkan, apalagi secara lingkungan akan lebih menguntungkan karena akan mengurangi dampak lingkungan.

Hasil analisis $\mathrm{BC}$ ratio pengembangan investasi eksternalitas sebagaimana dapat dilihat pada Tabel 4, menunjukkan nilai $\mathrm{BC}$ ratio ketiga perusahaan pada tingkat discount factor $10 \%$ secara konvensional ataupun secara eksternalitas ternyata lebih besar dari satu. 
Demikian juga nilai $\mathrm{BC}$ ratio pada tingkat discount factor 15\% secara konvensional ataupun secara eksternalitas lebih besar dari satu.

Hasil ini menunjukkan bahwa ketiga perusahaan sampel secara konvensional memberikan perbandingan antara pendapatan atau benefit dengan biaya investasi yang lebih besar dari satu artinya sudah layak secara finansial, demikian juga dengan rencana investasi eksternalitas memberikan perbandingan antara pendapatan atau benefit dengan biaya investasi yang lebih besar dari satu.Berdasarkan kriteria investasi hasil analisis ini menunjukkan bahwa pengembangan investasi eksternalitas pada perusahaan peternakan babi sampel di Kota Tomohon layak untuk dilaksanakan, dilanjutkan atau dikembangkan.

\section{KESIMPULAN}

Analisis finansial investasi eksternalitas atau lingkungan perusahaan peternakan babi di Kota Tomohon memberikan Nilai NPV, Nilai IRR, dan Nilai BC ratio yang masih menguntungkan, baik hanya secara konvensional maupun secara investasi eksternalitas atau lingkungan. Dengan demikianpengembangan investasilingkungan layak dilanjutkan atau dikembangkan.

\section{DAFTAR PUSTAKA}

Dewi, H.I., 2011. Upaya adjustment dan adaptasi untuk mengatasi eksternalitas ruang negatif. Jurnal Arsitektur Nalars 10(1):39-52.

Ditjennak Deptan, 2011. Rencana Strategis (Renstra) Direktorat Jenderal Peternakan dan KesehatanHewan Tahun 2010-2014. Direktorat Jenderal Peternakan dan Kesehatan Hewan Kementerian Pertanian, Jakarta.

Ditjennak Deptan, 2012. Pedoman Pelaksanaan Penataan Usaha Budidaya Babi Ramah Lingkungan Tahun 2012. http://www.deptan.go.id/pedum 2012/PETERNAKAN/1.8.1.\%20P edum $\% 20$ pemberdayaan $\% 20$ babi $\%$ 202012.pdfdiakses tanggal 21April 2019.

Gray C, P., Simanjuntak., L.K. Sabur., P.F.L. Maspaitella., R.C.G. Varley. 2001. Pengantar Evaluasi proyek. PT Gramedia Pustaka Utama, Jakarta

Hidayatullah, T., R.Y. Suryandari, A.C. Fitriyanto, dan I. Nahib, 2011. Pemetaan neraca dan valuasi ekonomi sumber daya pulau kecil. Geografia OnlineTM Malaysia Journal of Society and Space 7(1):87-92.

Loho, R., B. Rorimpandey., M. T. Massie., N. Santa. 2014. Analisis permintaan produk peternakan Di Desa Tawaang Kecamatan Tenga Kabupaten Minahasa Selatan. Jurnal Zootek. 34 (2) : 57-64

Mangare, G., B.F.J. Sondakh., F.S. Oley., M.T. Massie. 2016. Analisis karakteristik sosial ekonomi 
penyuluh dengan pelaksanaan penyuluhan di Kabupaten Minahasa Jurnal Zootek 36 (2) : 333-341

Mukhlis, I. 2011. Eksternalitas, Pertumbuhan Ekonomi dan Pembangunan Berkelanjutan dalam Perspektif Teoretis. Jurnal Ekonomi Bisnis 14(3) : 65-72

Morris J. 2013. Environmental Costs and Externalities. Sound Resource Management Group, Inc. Prepared for the Oregon Department of Environmental Quality.

Morissan. 2017. Metode Penelitian Survey. Cetakan ke 5. Penerbit Kencana Prenadameria Jakarta

Risman. 2016. Persepsi Masyarakat Terhadap Keberadaan Peternakan Babi. Skripsi. Jurusan Ilmu Peternakan Fakultas Sains Dan Teknologi Universitas Islam Negeri Alauddin Makassar.

Sapanca, P.L.Y., I. W. Cipta dan I. M. Suryana. 2015. Peningkatan manajemen kelompok ternak babi di Kabupaten Bangli. Agrimeta, Jurnal Pertanian berbasis Keseimbangan Ekosistem 5 (9) : 18-25

Sajow, A.A., B. Polii., E. Laoh. 2014. Kajian ekonomi dan lingkungan agribisnis peternakan babi di Kota Tomohon. Jurnal Zootek 34(1): 140-155

Timbulus, M.C., P.R.R.I Montong, A.D. Mirah., S. E. Siswosubroto. 2017. Penampilan produksi ternak babi grower yang menggunakan tepung kulit kopi sebagai bahan pengganti sebagian dedak halus pada pakan. Jurnal Zootek. 37(2): 242-251
Warouw, Z.M., V.V.J Panelewen, A.D.P Mirah. 2014. Analisis usaha peternakan babi pada perusahan "Kasewean" kakaskasen II kota Tomohon. Jurnal Zootek.34(1): 92-102

Wenedi, A. A. 2018. Analisis Finansial Usaha Ternak Babi (Studi Kasus Di Peternakan Babi UD Bisa Desa Cempokomulyo Kecamatan Kepanjen Kabupaten Malang). Thesis, Universitas Brawijaya. 